\title{
Membrane-Less Ethanol Electrooxidation over Pd-M (M: Sn, Mo and Re) Bimetallic Catalysts
}

\author{
Estela Ruiz-López ${ }^{1}{ }^{\circledR}$, Manuel Antonio Diaz-Perez ${ }^{2}{ }^{\circledR}$, Antonio de Lucas-Consuegra ${ }^{1}\left(\mathbb{D}\right.$, Fernando Dorado $^{1}{ }^{\mathbb{C}}$ \\ and Juan Carlos Serrano-Ruiz $2, * \mathbb{C}$ \\ 1 Department of Chemical Engineering, School of Chemical Sciences and Technologies, \\ University of Castilla-La Mancha, Avenida Camilo José Cela 12, 13005 Ciudad Real, Spain; \\ Estela.Ruiz@uclm.es (E.R.-L.); Antonio.LConsuegra@uclm.es (A.d.L.-C.); fernando.dorado@uclm.es (F.D.) \\ 2 Materials and Sustainability Group, Department of Engineering, Universidad Loyola Andalucía, Avda. \\ de las Universidades s/n, 41704 Dos Hermanas, Seville, Spain; madiaz@uloyola.es \\ * Correspondence: jcserrano@uloyola.es; Tel.: +34-955-641-600 (ext. 2579)
}

Citation: Ruiz-López, E.; Diaz-Perez,

M.A.; de Lucas-Consuegra, A.;

Dorado, F.; Serrano-Ruiz, J.C.

Membrane-Less Ethanol

Electrooxidation over Pd-M (M: Sn

Mo and Re) Bimetallic Catalysts.

Catalysts 2021, 11, 541.

https://doi.org/10.3390/catal11050541

Academic Editor: Carmelo Lo Vecchio

Received: 11 March 2021

Accepted: 21 April 2021

Published: 23 April 2021

Publisher's Note: MDPI stays neutral with regard to jurisdictional claims in published maps and institutional affiliations.

Copyright: (c) 2021 by the authors. Licensee MDPI, Basel, Switzerland. This article is an open access article distributed under the terms and conditions of the Creative Commons Attribution (CC BY) license (https:/ / creativecommons.org/licenses/by/ $4.0 /)$.
Abstract: The effect of the addition of three oxophilic co-metals (Sn, Mo and Re) on the electrochemical performance of $\mathrm{Pd}$ in the ethanol oxidation reaction (EOR) was investigated by performing half-cell and membrane-less electrolysis cell experiments. While the additions of $\mathrm{Sn}$ and Re were found to improve significantly the EOR performance of $\mathrm{Pd}$, Mo produced no significant promotional effect. When added in significant amounts (50:50 ratio), Sn and Re produced a 3-4 fold increase in the mass-normalized oxidation peak current as compared to the monometallic Pd/C material. Both the electrochemical surface area and the onset potential also improved upon addition of $\mathrm{Sn}$ and $\mathrm{Re}$, although this effect was more evident for Sn. Cyclic voltammetry (CV) measurements revealed a higher ability of $\mathrm{Sn}$ for accommodating $\mathrm{OH}$ - species as compared to Re, which could explain these results. Additional tests were carried out in a membrane-less electrolysis system. $\mathrm{Pd}_{50} \mathrm{Re}_{50} / \mathrm{C}$ and $\mathrm{Pd}_{50} \mathrm{Sn}_{50} / \mathrm{C}$ both showed higher activity than $\mathrm{Pd} / \mathrm{C}$ in this system. Chronopotentiometric measurements at constant current were carried out to test the stability of both catalysts in the absence of a membrane. $\mathrm{Pd}_{50} \mathrm{Sn}_{50} / \mathrm{C}$ was significantly more stable than $\mathrm{Pd}_{50} \mathrm{Re}_{50} / \mathrm{C}$, which showed a rapid increase in the potential with time. Despite operating in the absence of a membrane, both catalysts generated a high-purity (e.g., 99.99\%) hydrogen stream at high intensities and low voltages. These conditions could lead to significant energy consumption savings compared to commercial water electrolyzers.

Keywords: Ethanol electrooxidation; alkaline media; Membrane-less system; hydrogen production

\section{Introduction}

The reduction of anthropogenic carbon dioxide emissions is a priority worldwide. However, most of the energy consumed is currently supplied by fossil fuels, which inevitably results in growing concentrations of carbon dioxide in the atmosphere. The utilization of hydrogen in fuel-cell driven electrochemical devices is a promising strategy to decarbonize important sectors such as transportation and industry. Efforts are currently focused on developing technologies allowing generation of hydrogen from renewable sources instead of fossil fuels [1]. In this sense, water electrolysis is one of the most studied and used methods for obtaining green hydrogen [2-4]. However, despite the important advances made in this field, the high energy required to break the water molecule represents an important barrier and increases the production costs significantly. Recently, electrochemical reforming of alcohols (alcohols electrolysis) has demonstrated potential for producing pure hydrogen at lower potentials than those required for water electrolysis, thereby allowing significant energy savings $[5,6]$. For instance, the higher chemical reactivity of ethanol compared to water allows generating hydrogen with electrical energy savings higher than $50 \%$ (2.3 vs. $4.7 \mathrm{~kW} \mathrm{~h} / \mathrm{Nm}^{3} \mathrm{H}_{2}$ ). 
Since ethanol can be obtained from renewable sources (i.e., biomass) by well-developed and simple fermentation technologies, this compound has been commonly used to generate green hydrogen by means of this technology. The ethanol electrooxidation reaction (EOR) has been historically carried out in acidic media over platinum-based electrocatalysts $[7,8]$. However, recent studies have demonstrated that carrying out the EOR in alkaline media can be advantageous [9], with Pd showing high activity under these conditions [10]. With the aim to explain the high EOR activity of Pd in alkaline media, Liang et al. [11] proposed a four-step mechanism (Equations (1)-(4)). In this mechanism, $\mathrm{OH}^{-}$species adsorbed over $\mathrm{Pd}$ (i.e., $\mathrm{OH}_{\mathrm{ads}}$ ) were proposed to play a key role in the overall process by facilitating the oxidization of intermediate organic species strongly adsorbed on Pd (Equation (3)). This reaction has been identified as the rate-determining step of the overall process by several authors in previous works [11-14]. Once oxidized, these organic species are more easily released, allowing Pd sites to be recovered for a new oxidation cycle (Equation (4)).

$$
\begin{gathered}
\mathrm{Pd}+\mathrm{CH}_{3} \mathrm{CH}_{2} \mathrm{OH} \leftrightarrow \mathrm{Pd}-\left(\mathrm{CH}_{3} \mathrm{CH}_{2} \mathrm{OH}\right)_{\text {ads }} \\
\mathrm{Pd}-\left(\mathrm{CH}_{3} \mathrm{CH}_{2} \mathrm{OH}\right)_{\mathrm{ads}}+3 \mathrm{OH}^{-} \rightarrow \mathrm{Pd}-\left(\mathrm{CH}_{3} \mathrm{CO}\right)_{\text {ads }}+3 \mathrm{H}_{2} \mathrm{O}+3 \mathrm{e}^{-} \\
\mathrm{Pd}-\left(\mathrm{CH}_{3} \mathrm{CO}\right)_{\mathrm{ads}}+\mathrm{Pd}-\mathrm{OH}_{\mathrm{ads}} \rightarrow \mathrm{Pd}-\mathrm{CH}_{3} \mathrm{COOH}+\mathrm{Pd} \text { rate determining step } \\
\mathrm{Pd}-\mathrm{CH}_{3} \mathrm{COO}^{-}+\mathrm{H}_{2} \mathrm{O} \rightarrow \mathrm{Pd}+\mathrm{CH}_{3} \mathrm{COO}^{-}+\mathrm{H}_{2} \mathrm{O}
\end{gathered}
$$

According to this mechanism, the presence of $\mathrm{OH}_{\text {ads }}$ species in the vicinities of $\mathrm{Pd}$ can help increase both the EOR activity and stability of the noble metal. In line with this approach, the addition of a second metal able to accommodate $\mathrm{OH}^{-}$species has been commonly used to improve the EOR performance of $\mathrm{Pd}$. Metals such as $\mathrm{Ru}, \mathrm{Cu}, \mathrm{Ni}, \mathrm{Pb}$, $\mathrm{Ag}$, $\mathrm{Au}$ and $\mathrm{Sn}$ have been typically added to $\mathrm{Pd}$, resulting in catalysts with improved EOR performance as compared to their monometallic counterparts [15-26]. This strategy has also allowed us to significantly reduce the Pd content of the electrocatalysts, which is desirable in view of the high cost and low abundance of this noble metal.

While $\mathrm{Sn}$ has been widely studied as a EOR Pd co-metal in basic media [20,27-30], other co-metals such as Mo and Re have received significantly less attention despite their well-known oxophilicity and their outstanding ability to accommodate hydroxyl species [31-36]. Mo has been used in combination with Pt to electrooxydize several biomassderived oxygenated molecules such as ethanol [31] and glycerol [32]. Pd-Mo catalysts have demonstrated high activity towards the electrooxidation of ethylene glycol [33]. Lim et al. [34] studied the electrooxidation of methanol and ethanol in alkaline media over different $\mathrm{MoO}_{\mathrm{x}}-\mathrm{Pd}$ materials and found a significant improvement in the mass activity as compared to monometallic $\mathrm{Pd} / \mathrm{C}$. With regard to $\mathrm{Re}$, in addition to its ability to adsorb $\mathrm{OH}_{\text {ads }}$ species, it has also demonstrated significant activity to promote $\mathrm{C}-\mathrm{C}$ cleavage of oxygenated molecules such as glycerol when combined with $\mathrm{Pt}$ [36]. In this sense, the addition of $\mathrm{Re}$ to $\mathrm{Pt} / \mathrm{C}$ and $\mathrm{Pt}-\mathrm{Sn} / \mathrm{C}$ catalysts improved the ethanol electrooxidation activity of these materials, and this was ascribed to the ability of Re to promote $C-C$ breaking of intermediates adsorbed on the noble metal [36].

In this work, we explored the effects of Mo and Re on the EOR performance of $\mathrm{Pd}$ in alkaline media (mostly activity and stability). These effects were compared with those produced by a more common and well-known additive such as Sn. The structures of the bimetallic catalysts prepared were studied by X-ray diffraction (XRD), and their electrooxidation performances were evaluated by cyclic voltammetry $(\mathrm{CV})$ measurements via half-cell experiments. The performance of the most promising catalysts was additionally studied in detail in a membrane-less electrolysis cell [6]. This membrane-less configuration uses a liquid electrolyte instead of commercial polymeric membranes. This configuration is interesting in that it allows operating without membranes, which are one of the critical components of electrolysers, being responsible for the high prices and limited life-times of these devices. Thus, a membrane-less electrolyser can potentially overcome mechanical, 
chemical or electrochemical failures produced by membrane degradation while reducing the capital costs of these devices [37-39].

\section{Results and Discussion}

\subsection{Structural Characterization}

The diffraction patterns of $20 \% \mathrm{Pd} / \mathrm{C}$ and the bimetallic $20 \% \mathrm{Pd}$-metal/C materials are shown in Figure 1. Additionally, the XRD patterns of monometallic Sn, Re and Mo catalysts and C Vulcan are shown in Figure S1 for the sake of comparison. As shown in Figure 1, all the samples showed a peak at ca. $25^{\circ}$, which was ascribed to the (002) plane of the hexagonal structure of the carbon material used as a support (denoted as C (002)). The presence of Pd nanoparticles with a face-centered cubic (fcc) structure was confirmed by their characteristic peaks at ca. 40,47, 68 and $83^{\circ}$, corresponding to the (111), (200), (220), (311) and (222) planes, respectively. No significant shifts in the diffraction angles of these Pd diffraction peaks were observed upon addition of any of the co-metals tested herein. A slight shift (below $0.14^{\circ}$ ) was found in the case of $20 \%$ Pd50Re50/C. However, this shift is not high enough to be considered as a proof of an alloy formation, according to previous works [29]. The intensity of the Pd diffraction peaks decreased when increasing the co-metal loading from a 70:30 to 50:50 ratio. As shown in Table 1, the addition of a second metal to Pd resulted in slight changes in the Pd crystallite size. These particle sizes were calculated by the Scherrer equation using the full width at half maximum (FWHM) of the $\mathrm{Pd}(111)$ peak (Table 1). Both the decrease in intensity of the Pd diffraction peaks and the changes in particle size revealed a certain degree of interaction between Pd and the co-metal. No evidence of peaks ascribed to co-metals used (i.e., Sn, Mo and Re) or their oxides was found in the diffractograms. However, it is likely that they were present as amorphous oxide or hydroxide phases or formed alloys with Pd, as previously reported in similar Pd-metals systems [27,29,40].

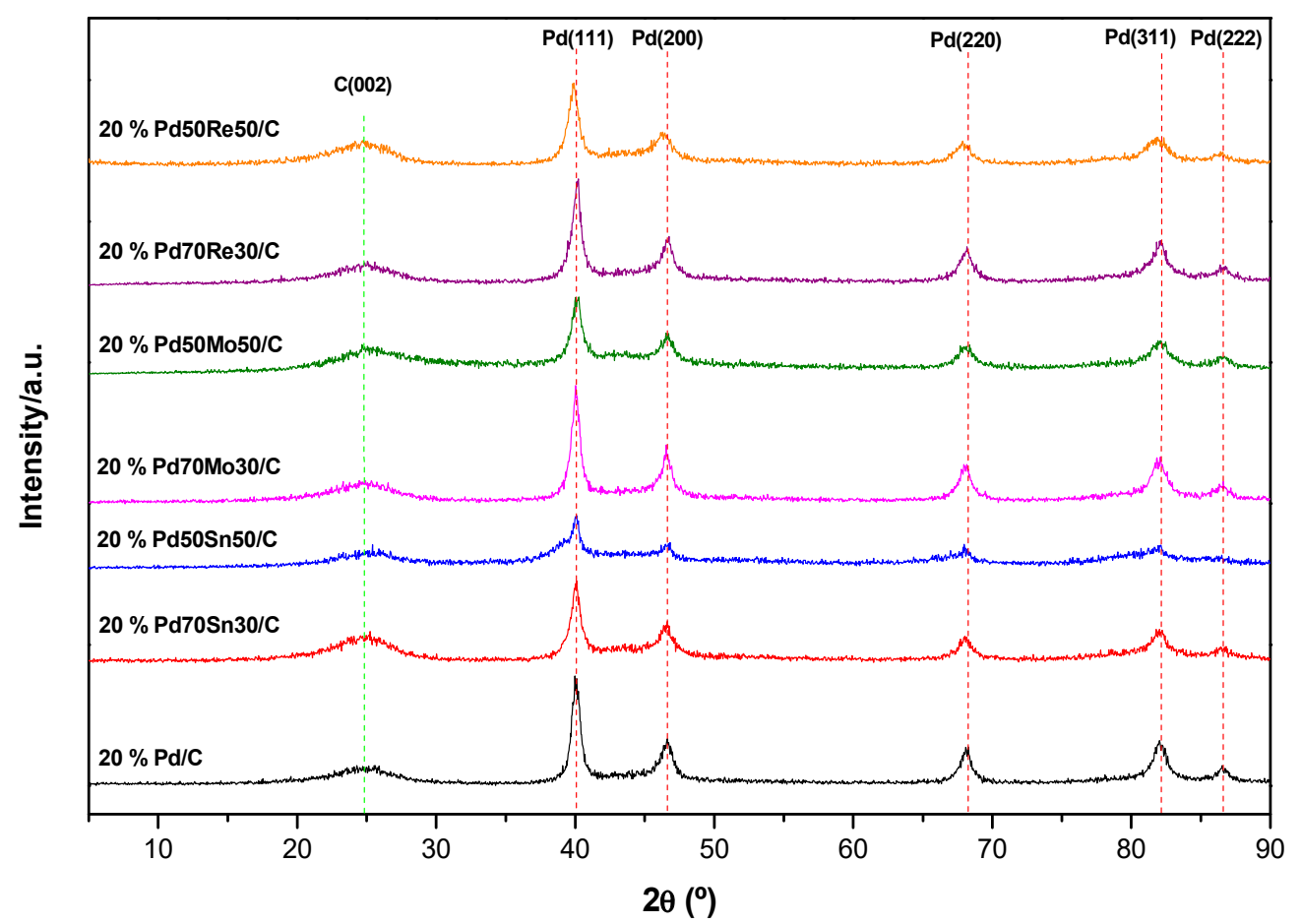

Figure 1. XRD diffractograms of $20 \% \mathrm{Pd} / \mathrm{C}$ and the bimetallic samples of $20 \%$ Pd-metal/C. 
Table 1. Crystallite size obtained from X-ray diffraction analyses and electrochemical surface area (ECSA) obtained from electrochemical measurements.

\begin{tabular}{cccc}
\hline Catalyst. & FWHM $\boldsymbol{(}^{\circ}$ & $\begin{array}{c}\text { Pd mean Crystallite } \\
\text { Size } \\
(\mathbf{n m})\end{array}$ & $\begin{array}{c}\text { ECSA } \\
\left(\mathbf{m}^{\mathbf{2}} \mathbf{g}^{-\mathbf{1}} \mathbf{)}\right.\end{array}$ \\
\hline $20 \% \mathrm{Pd} / \mathrm{C}$ & 0.8826 & 9.580 & 6.78 \\
$20 \% \mathrm{Pd}_{70} \mathrm{Sn}_{30} / \mathrm{C}$ & 0.9999 & 8.456 & 9.17 \\
$20 \% \mathrm{Pd}_{50} \mathrm{Sn}_{50} / \mathrm{C}$ & 0.7537 & 11.218 & 67.61 \\
$20 \% \mathrm{Pd}_{70} \mathrm{Mo}_{30} / \mathrm{C}$ & 0.8314 & 10.172 & 4.80 \\
$20 \% \mathrm{Pd}_{50} \mathrm{Mo}_{50} / \mathrm{C}$ & 1.0331 & 8.186 & 5.52 \\
$20 \% \mathrm{Pd}_{70} \mathrm{Re}_{30} / \mathrm{C}$ & 0.8633 & 9.798 & 2.44 \\
$20 \% \mathrm{Pd}_{50} \mathrm{Re}_{50} / \mathrm{C}$ & 0.9738 & 8.680 & 21.22 \\
\hline
\end{tabular}

\subsection{Electrochemical Measurements}

\subsection{1. $\mathrm{CV}$ in Aqueous $\mathrm{KOH}$}

Figure 2 and Figure $\mathrm{S} 3$ show the CV profiles of the different catalysts prepared herein.

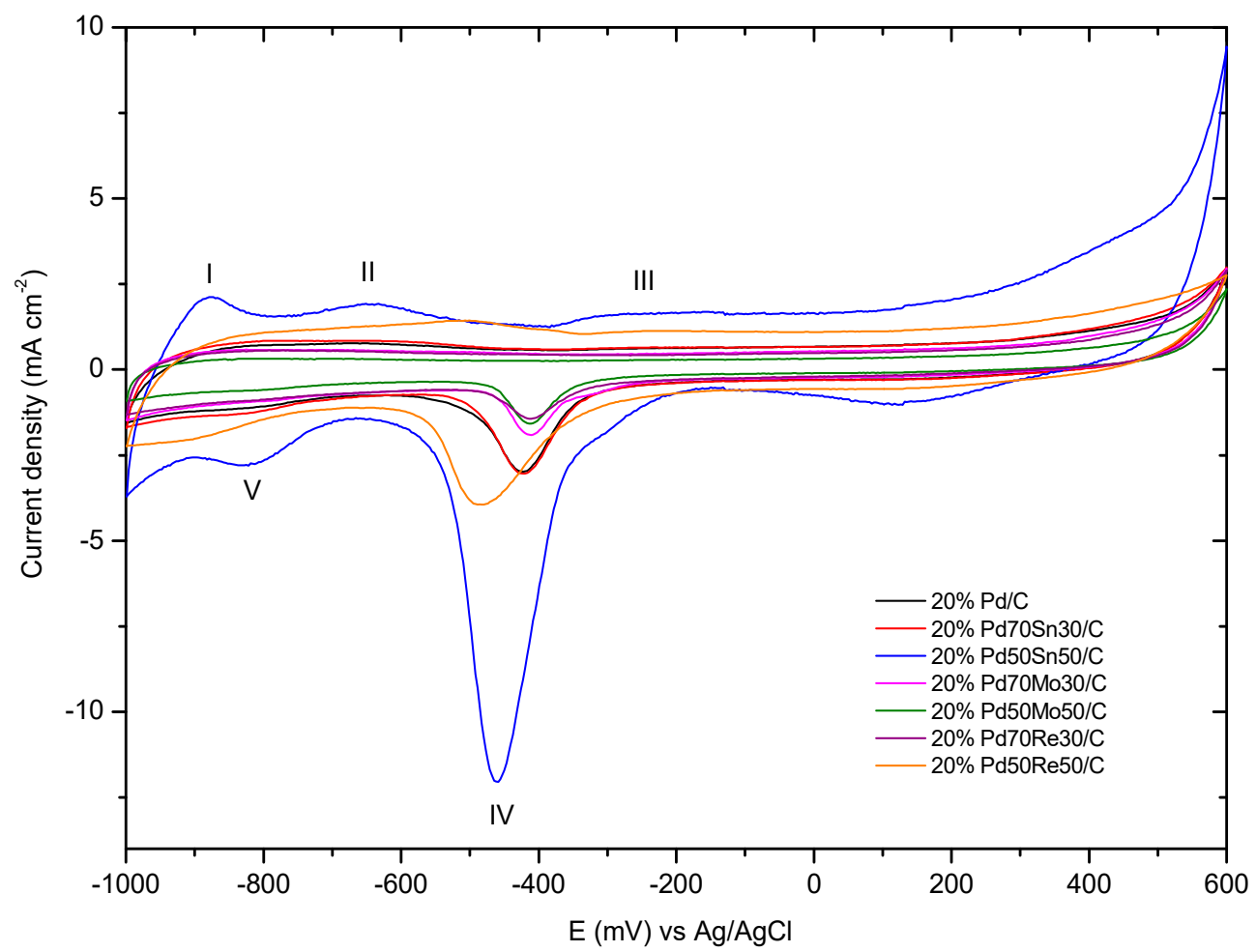

Figure 2. Cyclic voltammograms of $20 \% \mathrm{Pd} / \mathrm{C}, 20 \% \mathrm{Pd}_{70} \mathrm{Sn}_{30} / \mathrm{C}, 20 \% \mathrm{Pd}_{50} \mathrm{Sn}_{50} / \mathrm{C}, 20 \% \mathrm{Pd}_{70} \mathrm{Mo}_{30} / \mathrm{C}$, $20 \% \mathrm{Pd}_{50} \mathrm{Mo}_{50} / \mathrm{C}, 20 \% \mathrm{Pd}_{70} \mathrm{Re}_{30} / \mathrm{C}$ and 20\% $\mathrm{Pd}_{50} \mathrm{Re}_{50} / \mathrm{C}$ in $\mathrm{KOH} 1.0 \mathrm{M} . \mathrm{E}(\mathrm{mV})$ vs. $\mathrm{Ag} / \mathrm{AgCl}(3 \mathrm{M})$. (Scan rate: $50 \mathrm{mV} \mathrm{s}^{-1}$ at room temperature).

Five different peaks were observed in the $\mathrm{CV}$ profiles, in line with previous works [11,41]. As shown in Figure 2, the positive-scan revealed three oxidation peaks (I, II and III). Peak I between -900 and $-800 \mathrm{mV}$ was ascribed to the electrochemical oxidation of the hydrogen adsorbed on Pd, according to the following Equation:

$$
\mathrm{Pd}-\mathrm{H}_{\mathrm{abs}-\mathrm{ads}}+\mathrm{OH}^{-} \rightarrow \mathrm{Pd}+\mathrm{H}_{2} \mathrm{O}+\mathrm{e}^{-}
$$

Peak II, centered at around $-650 \mathrm{mV}$, corresponds to the adsorption of hydroxyl groups on Pd:

$$
\mathrm{Pd}+\mathrm{OH}^{-} \rightarrow \mathrm{Pd}-\mathrm{OH}_{\mathrm{ads}}+\mathrm{e}^{-}
$$


Peak III at ca. $-300 \mathrm{mV}$ was ascribed to the formation of Pd (II) oxide in virtue of processes (7) and (8):

$$
\begin{gathered}
\mathrm{Pd}-\mathrm{OH}_{\mathrm{ads}}+\mathrm{OH}^{-} \rightarrow \mathrm{Pd}-\mathrm{O}+\mathrm{H}_{2} \mathrm{O}+\mathrm{e}^{-} \\
\mathrm{Pd}-\mathrm{OH}_{\mathrm{ads}}+\mathrm{Pd}-\mathrm{OH}_{\mathrm{ads}} \rightarrow \mathrm{Pd}-\mathrm{O}+\mathrm{H}_{2} \mathrm{O}
\end{gathered}
$$

In regard to the cathodic scan, an intense and well-defined peak was observed at ca. $-450 \mathrm{mV}$ (peak IV). This large peak was ascribed to the reduction of the Pd oxide layers previously formed by Equations (7) and (8).

$$
\mathrm{Pd}-\mathrm{O}+\mathrm{H}_{2} \mathrm{O}+2 \mathrm{e}^{-} \rightarrow \mathrm{Pd}+2 \mathrm{OH}^{-}
$$

An additional reduction peak (peak V) was observed during the backward scan. This reduction peak was ascribed to the adsorption of hydrogen on Pd.

The electrochemical surface area of the catalysts (ECSA, Table 1) was calculated from the CV curves in Figure 2, considering the area under the large reduction current of PdO (peak IV) $[14,29,42,43]$. These ECSA values were obtained as follows:

$$
\text { ECSA }=\frac{\mathrm{Q}(\mu \mathrm{C})}{\mathrm{Q}_{\mathrm{PdO}}\left(\mu \mathrm{C} \cdot \mathrm{cm}_{\mathrm{Pd}}^{-2}\right) \cdot \operatorname{Pd}_{\text {loading }}(\mathrm{mg}) \cdot 10}
$$

where $\mathrm{Q}_{\mathrm{PdO}}$ is the charge required to reduce a PdO monolayer $(405 \mu \mathrm{C} \mathrm{cm}-2)[14,29], \mathrm{Q}$ is the columbic charge estimated as the area under the reduction peak IV and $\mathrm{Pd}_{\text {loading }}$ is the mass of Pd of the electrode. Note that the contribution of cometal oxides to the reduction peak IV have been neglected ( $\mathrm{Sn}$ and $\mathrm{Mo}$ ) and/or corrected (Re) according to the $\mathrm{CV}$ tests developed with $20 \% \mathrm{Sn} / \mathrm{C}, 20 \% \mathrm{Mo} / \mathrm{C}$ and $20 \% \mathrm{Re} / \mathrm{C}$ in a solution of $\mathrm{KOH} 1 \mathrm{M}$ (Figure S2). Remarkably, $20 \% \mathrm{Pd}_{50} \mathrm{Sn}_{50} / \mathrm{C}$ and $20 \% \mathrm{Pd}_{50} \mathrm{Re}_{50} / \mathrm{C}$ showed ECSA values significantly higher than the rest of catalysts, including monometallic $20 \% \mathrm{Pd} / \mathrm{C}$. As shown in Table 1, ECSA followed the trend $20 \% \mathrm{Pd}_{50} \mathrm{Sn}_{50} / \mathrm{C}>20 \% \mathrm{Pd}_{50} \mathrm{Re}_{50} / \mathrm{C}>20 \% \mathrm{Pd}_{70} \mathrm{Sn}_{30} / \mathrm{C}>20 \%$ $\mathrm{Pd} / \mathrm{C}>20 \% \mathrm{Pd}_{50} \mathrm{Mo}_{50} / \mathrm{C}>20 \% \mathrm{Pd}_{70} \mathrm{Mo}_{30} / \mathrm{C}>20 \% \mathrm{Pd}_{70} \mathrm{Re}_{30} / \mathrm{C}$.

\subsubsection{EOR Performance in $\mathrm{KOH}-\mathrm{EtOH}$ Aqueous Solutions}

The EOR electrochemical activity of the synthesized catalysts was investigated in a half-cell at room temperature in $\mathrm{KOH}$-ethanol aqueous solutions. The $\mathrm{CV}$ profiles of the catalysts are shown in Figure 3, and the most relevant electrochemical parameters obtained from these $\mathrm{CV}$ curves are summarized in Table 2. For the sake of comparison, we performed $\mathrm{CV}$ analyses over monometallic Sn, Mo and Re catalysts (Figure S4). As shown in Figure S4, monometallic Sn, Mo and Re materials showed no EOR activity. As can be inferred from Figure S4, the support (carbon Vulcan) was unreactive towards the EOR.

\begin{tabular}{|c|c|c|}
\hline Catalyst & $E_{\text {onset }}(\mathrm{mV})^{a}$ & $i_{m}(m A \mu g P d-1) b$ \\
\hline $20 \% \mathrm{Pd} / \mathrm{C}$ & -700 & 0.063 \\
\hline $20 \% \mathrm{Pd}_{70} \mathrm{Sn}_{30} / \mathrm{C}$ & -725 & 0.216 \\
\hline $20 \% \mathrm{Pd}_{50} \mathrm{Sn}_{50} / \mathrm{C}$ & -750 & 0.292 \\
\hline $20 \% \mathrm{Pd}_{70} \mathrm{Mo}_{30} / \mathrm{C}$ & -670 & 0.063 \\
\hline $20 \% \mathrm{Pd}_{50} \mathrm{Mo}_{50} / \mathrm{C}$ & -660 & 0.068 \\
\hline $20 \% \mathrm{Pd}_{70} \operatorname{Re}_{30} / \mathrm{C}$ & -680 & 0.060 \\
\hline $20 \% \mathrm{Pd}_{50} \operatorname{Re}_{50} / \mathrm{C}$ & -740 & 0.237 \\
\hline
\end{tabular}

Table 2. Main electrochemical parameters for the different catalysts studied obtained from cyclic voltammograms in $\mathrm{KOH} 1.0 \mathrm{~mol} \mathrm{~L}^{-1}$ solution containing EtOH $1.0 \mathrm{~mol} \mathrm{~L}-1$. (Scan rate $=50 \mathrm{mV} \mathrm{s}^{-1}$ at room temperature).

${ }^{a}$ Onset potential (mV vs. $\left.\mathrm{Ag} / \mathrm{AgCl} 3 \mathrm{M}\right) \cdot{ }^{\mathrm{b}}$ Mass-normalized peak current $\left({\left.\mathrm{mA} \mu \mathrm{gPd}^{-1}\right)}^{-}\right.$ 


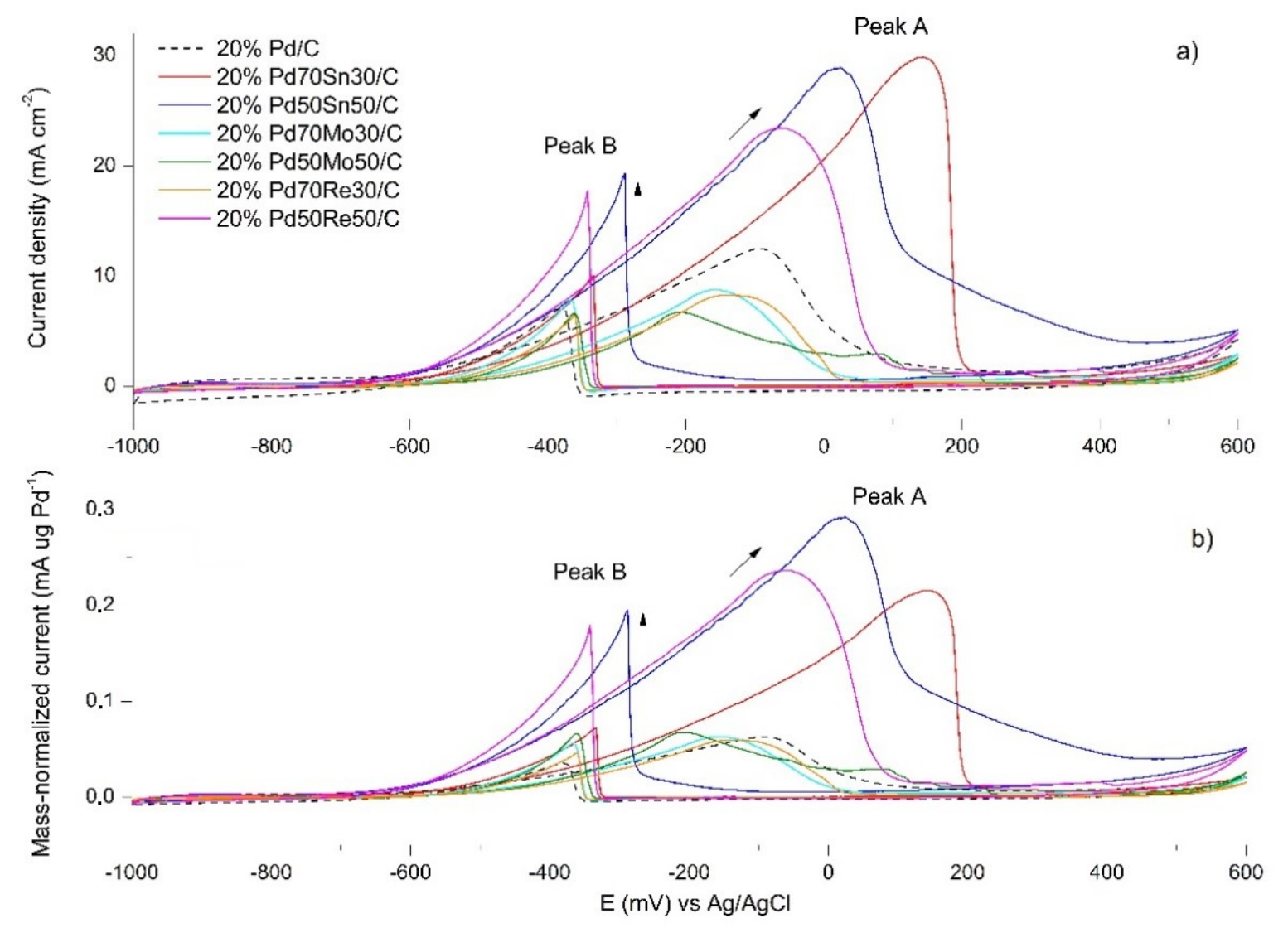

Figure 3. Cyclic voltammograms of $20 \% \mathrm{Pd} / \mathrm{C}, 20 \% \mathrm{Pd}_{70} \mathrm{Sn}_{30} / \mathrm{C}, 20 \% \mathrm{Pd}_{50} \mathrm{Sn}_{50} / \mathrm{C}, 20 \% \mathrm{Pd}_{70} \mathrm{Mo}_{30} / \mathrm{C}, 20 \% \mathrm{Pd}_{50} \mathrm{Mo}_{50} / \mathrm{C}$, $20 \% \mathrm{Pd}_{70} \mathrm{Re}_{30} / \mathrm{C}$ and $20 \% \mathrm{Pd}_{50} \mathrm{Re}_{50} / \mathrm{C}$ in a solution of $\mathrm{KOH} 1.0 \mathrm{~mol} \mathrm{~L}^{-1}+\mathrm{EtOH} 1.0 \mathrm{~mol} \mathrm{~L}^{-1}$. (a) Current density $\left(\mathrm{mA} \mathrm{cm}^{-2}\right)$ versus Voltage $(\mathrm{mV})$; (b) Mass-normalized current $\left(\mathrm{mA} \mu \mathrm{g} \mathrm{Pd}^{-1}\right)$ versus Voltage $(\mathrm{mV})$. E (mV) vs. $\mathrm{Ag} / \mathrm{AgCl}(3 \mathrm{M})$. (Scan rate: $50 \mathrm{mV} \mathrm{s}^{-1}$ at room temperature).

As shown in Figure 3a, ethanol oxidation started below $-600 \mathrm{mV}$ for the most active catalysts. At this point, ethanol is adsorbed, generating intermediate species as a result of the oxidation process (Equation (2)). Hydroxyl groups are also adsorbed at this range of potential (Equation (6)), favoring the desorption of intermediates and allowing electrooxidation to proceed continuously before reaching the maximum of the current density (peak A). At this point, the build-up of Pd-O (Equations (7) and (8)) at higher potentials blocks $\mathrm{Pd}$ active sites and the current density drops as a result. Nonetheless, the electro activity of the catalyst is recovered during the backward scan, as evidence by the presence of a further peak (peak B) generated by the oxidation of the reaction intermediates $[11,17]$. As shown in Figure $3 a$, the addition of $S n$ and $\operatorname{Re}$ (at 50:50 ratio) significantly increased the EOR activity of Pd. When expressed in terms of mass of Pd (mA $\mu \mathrm{g} \mathrm{Pd}^{-1}$; Figure $\left.3 \mathrm{~b}\right)$, the promotional effects of $\mathrm{Sn}$ and Re are clearly appreciated. Sn-containing catalysts and $20 \% \mathrm{Pd}_{50} \operatorname{Re}_{50} / \mathrm{C}$ showed mass-normalized peak currents $\left(\mathrm{i}_{\mathrm{m}}\right)$ 3-4 times higher than that of $20 \% \mathrm{Pd} / \mathrm{C}$, whereas the rest of catalysts showed peak currents similar to that of the monometallic material. In the case of $20 \% \mathrm{Pd}_{50} \mathrm{Sn}_{50} / \mathrm{C}$, this high electrooxidation activity correlates well with the presence of an intense peak II (Figure 2) corresponding to the adsorption of $\mathrm{OH}_{\text {ads }}$ species. As indicated previously, these $\mathrm{OH}_{\text {ads }}$ species can subsequently participate in the oxidation of intermediates strongly adsorbed on Pd. Peak II was less prominent for the $20 \% \mathrm{Pd}_{70} \mathrm{Sn}_{30} / \mathrm{C}$ and $20 \% \mathrm{Pd}_{50} \operatorname{Re}_{50} / \mathrm{C}$ catalysts. Remarkably, 20\% $\mathrm{Pd}_{50} \operatorname{Re}_{50} / \mathrm{C}$ showed current densities comparable to those of $20 \% \mathrm{Pd}_{50} \mathrm{Sn}_{50} / \mathrm{C}$ despite having three times lower ECSA (Table 1).

As pointed out in the Introduction, the electrochemical reforming of ethanol can be highly beneficial, since it happens at lower potentials than water electrolysis, resulting in a reduction in the electrical power necessary to produce hydrogen. Hence, the lower the 
onset potential, the higher the potential beneficial effect. Table 2 shows the onset potential (obtained from Figure S5) for the monometallic $\mathrm{Pd}$ and the bimetallic catalysts. Additionally, $20 \% \mathrm{Pd}_{50} \mathrm{Sn}_{50} / \mathrm{C}, 20 \% \mathrm{Pd}_{50} \mathrm{Re}_{50} / \mathrm{C}$ and $20 \% \mathrm{Pd}_{70} \mathrm{Sn}_{30} / \mathrm{C}$ showed onset potentials 50, 40 and $25 \mathrm{mV}$ lower than that of $20 \% \mathrm{Pd} / \mathrm{C}$, respectively. It is interesting to note that the onset potential trend agrees well with that of the ECSA.

Unlike Sn and Re, the addition of Mo produced no significant promotional effect on the EOR performance of Pd: $20 \%$ Mo-containing bimetallic catalysts showed similar massnormalized peak currents and slightly higher onset potentials than $20 \% \mathrm{Pd} / \mathrm{C}$ (Table 2). Thus, despite its high oxophilicity [44], Mo did not increase significantly the EOR activity of Pd. Previous results from Robinson et al. pointed out that, when added in large amounts, Mo tends to form molybdenum oxide, which can block active Pd surface sites [45,46]. Similarly, Ordoñez et al. [47] found that high loadings of Mo decreased the activity of Pt during the electrooxidation of methanol in acidic medium.

\subsubsection{Membrane-Less Electrochemical Reforming Experiments.}

We selected the most promising catalysts in terms of ECSAs, onset potentials and mass-normalized peak current $\left(20 \% \mathrm{Pd}_{50} \mathrm{Sn}_{50} / \mathrm{C}\right.$ and $\left.20 \% \mathrm{Pd}_{50} \mathrm{Re}_{50} / \mathrm{C}\right)$ for subsequent membrane-less ethanol electrolysis experiments. The performance of these catalysts was compared with that of $20 \% \mathrm{Pt} / \mathrm{C}$. The electrochemical tests were carried out under optimal conditions, which were identified in a previous study [6]. The linear sweep voltammetry profiles of the three catalysts are shown Figure 4. None of the catalysts showed mass transfer limitations, with both bi-metallic catalysts showing higher mass activity than $\mathrm{Pd} / \mathrm{C}$, in line with half-cell experiments.

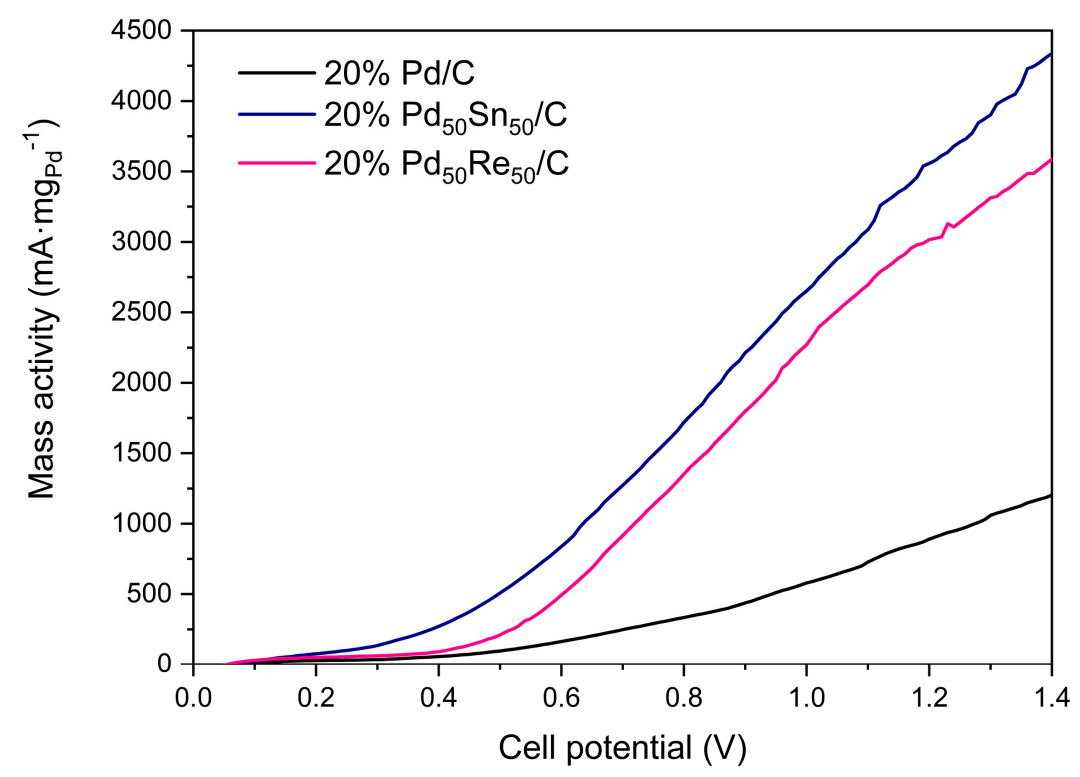

Figure 4. Membrane-less linear sweep voltammetry measurements (mass activity vs. cell potential). Scan rate $=10 \mathrm{mV} \cdot \mathrm{s}^{-1}$. Inlet composition $=1 \mathrm{~mol} \cdot \mathrm{L}^{-1} \mathrm{EtOH}$ and $4 \mathrm{~mol} \cdot \mathrm{L}^{-1} \mathrm{KOH} . \mathrm{T}=85^{\circ} \mathrm{C}$.

We tested the stability of both bimetallic catalysts by monitoring the variation of the potential versus time at constant intensity $(0.5 \mathrm{~A})$. Eight cycles of $1 \mathrm{~h}$ duration were carried out (Figure 5). Open circuit conditions were applied for $30 \mathrm{~s}$ after each cycle. 


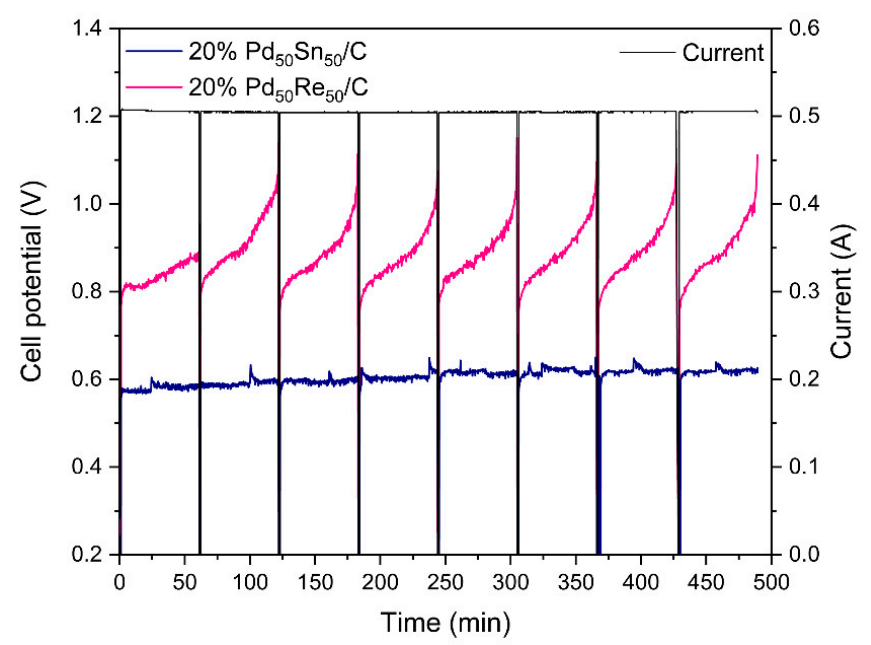

Figure 5. Stability test: chronopotentiometry experiments, galvanostatic cycles. Applied current $=$ $0.5 \mathrm{~A}$. Inlet composition $=1 \mathrm{~mol} \cdot \mathrm{L}^{-1} \mathrm{EtOH}$ and $1 \mathrm{~mol} \cdot \mathrm{L}^{-1} \mathrm{KOH} . \mathrm{T}=85^{\circ} \mathrm{C}$.

As shown in Figure 5, 20\% $\mathrm{Pd}_{50} \mathrm{Sn}_{50} / \mathrm{C}$ was significantly more stable than $\mathrm{Pd}_{50} \mathrm{Re}_{50} / \mathrm{C}$, which showed a continuous increase in voltage with time. This behavior has been previously ascribed to intermediate species remaining adsorbed on the catalyst surface, increasing the anodic polarization resistance as a result $[6,43,46]$. Open circuit conditions allowed these intermediates to desorb, recovering the initial voltage values. These results are in line with those reported by Bonarowska et al. [48]. These authors reported higher hydrocarbon hydrogenolysis activities and lower stability of $\mathrm{Pd} / \mathrm{Al}_{2} \mathrm{O}_{3}$ catalysts upon addition of Re. The poorer stability of the bimetallic materials was ascribed to deactivation of the catalyst surface by strongly adsorbed reaction intermediates. The lower ECSA of the $20 \% \mathrm{Pd}_{50} \mathrm{Re}_{50} / \mathrm{C}$ catalyst compared to $20 \% \mathrm{Pd}_{50} \mathrm{Sn}_{50} / \mathrm{C}\left(22 \mathrm{vs} .67 \mathrm{~m}^{2} \mathrm{~g}^{-1}\right.$ ) can also explain its faster deactivation. The $20 \% \mathrm{Pd}_{50} \mathrm{Sn}_{50} / \mathrm{C}$ catalysts maintained good stability with time while operating at voltages significantly lower than $\mathrm{Pd}_{50} \mathrm{Re}_{50} / \mathrm{C}$. As revealed by the $\mathrm{CV}$ profiles (peak II in Figure 2), $20 \% \mathrm{Pd}_{50} \mathrm{Sn}_{50} / \mathrm{C}$ showed higher affinity for $\mathrm{OH}_{\text {ads }}$ species than its Re counterpart, and this could facilitate the release of adsorbed reaction intermediates during the electrooxidation process, avoiding anodic polarization resistance issues.

One of the key elements of the EOR technology is the possibility of producing hydrogen at voltages significantly lower than those required for water electrolysis, thereby reducing the energy consumption. The energy requirements for the production of $1 \mathrm{~kg}$ of hydrogen over both bimetallic catalysts were calculated and the results are shown in Figure 6. Galvanostatic transients were carried from 0.1 to $0.7 \mathrm{~A}$ for $20 \% \mathrm{Pd}_{50} \mathrm{Re}_{50} / \mathrm{C}$ and from 0.1 to $2.0 \mathrm{~A}$ for $20 \% \mathrm{Pd}_{50} \mathrm{Sn}_{50} / \mathrm{C}$. These limits were set to avoid high voltages leading to water oxidation. The hydrogen production rate was experimentally measured, obtaining faradaic values in all cases. Despite operating without a separating membrane, high purity $(99.99 \%)$ hydrogen was obtained in the cathodic chamber in all cases. As shown in Figure 6, $\mathrm{Pd}_{50} \mathrm{Sn}_{50} / \mathrm{C}$ showed lower energy consumption values than $\mathrm{Pd}_{50} \mathrm{Re}_{50} / \mathrm{C}$ over the entire range of intensities tested herein. However, both catalysts present energy consumption well below those reported for commercial water PEM or alkaline electrolyzers (50-60 $\left.\mathrm{kWh} \cdot \mathrm{kg}_{\mathrm{H} 2}{ }^{-1}\right)$ [47]. Remarkably, the membrane-less configuration tested herein showed similar energy consumptions than ethanol electrolyzers containing a membrane as an electrolyte and operating under similar conditions $\left(18-30 \mathrm{kWh} \cdot \mathrm{kg}_{\mathrm{H} 2}{ }^{-1}\right)[49,50]$. 


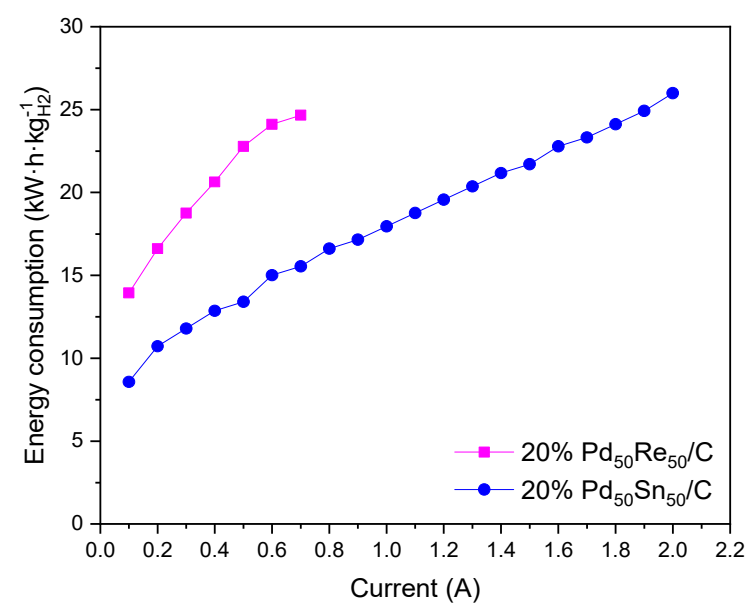

Figure 6. Energy requirements to produce $1 \mathrm{~kg}$ of hydrogen at different applied currents.

\section{Materials and Methods}

\subsection{Synthesis and Characterization of Pd-Based Catalyst Powders}

The synthesis of the different mono and bimetallic catalysts was carried out by the coreduction method of mixed precursor salts as described elsewhere [51,52]. Firstly, the corresponding active phase precursors were diluted in $50 \mathrm{~mL}$ of ethylene glycol. The active precursors used were $\mathrm{PdCl}_{2}$ (Sigma Aldrich, St. Louis, MO, United States), $\mathrm{H}_{24} \mathrm{Mo}_{7} \mathrm{~N}_{6} \mathrm{O}_{24} \cdot 4 \mathrm{H}_{2} \mathrm{O}$ (Fluka Analytical, München, Germany), $\mathrm{NH}_{4} \mathrm{ReO}_{4}$ (Sigma Aldrich, St. Louis, MO, United States) and $\mathrm{C}_{4} \mathrm{H}_{6} \mathrm{O}_{4} \mathrm{Sn}$ (Alfa Aesar, Kandel, Germany). Sodium hydroxide was added to the solution to prepare a $0.2 \mathrm{M} \mathrm{NaOH}$ (basic $\mathrm{pH}$ close to 9). The resulting solutions were stirred for $2 \mathrm{~h}$ at $190^{\circ} \mathrm{C}$, achieving a colloidal suspension. Carbon Vulcan XC-72 with a typical bulk density of $96 \mathrm{~kg} / \mathrm{m}^{3}\left(6 \mathrm{lbs} / \mathrm{ft}^{3}\right)$ and an average particle size of $50 \mathrm{~nm}$ (Fuel Cell Store) was added to the colloidal suspension and the resulting suspension was stirred for additional 48 $\mathrm{h}$ at room temperature. The catalysts powder obtained was washed with water, filtered and dried before use.

The three different co-metals used herein ( $\mathrm{Sn}, \mathrm{Mo}$ and $\mathrm{Re}$ ) were added to Pd in varying amounts. Moreover, monometallic Pd (reference catalyst) Sn, Mo and Re catalysts were also synthesized for the sake of comparison. All these catalysts were supported on carbon Vulcan XC-72, and the overall metal loading was $20 \mathrm{wt} \%$ in all cases. The actual metal loadings were close to the nominal values, as determined by inductively coupled plasma (ICP) (nominal value $\pm 0.4 \%$ ). ICP analyses were developed using a VARIAN Liberty RL sequential ICP-AES. Prior to the analysis, $0.5 \mathrm{~g}$ of the samples were treated with 2 $\mathrm{mL}$ of hydrochloric acid, $3 \mathrm{~mL}$ of hydrofluoric acid and $2 \mathrm{~mL}$ of hydrogen peroxide, followed by microwave digestion at $250^{\circ} \mathrm{C}$. Table 3 lists all the catalysts prepared and their corresponding metal contents.

XRD analysis was performed to identify the different crystalline structures of the synthesized catalysts. A PHILIPS PW-1710 diffractometer (Almelo, The Netherlands) with nickel-filtered $\mathrm{Cu}-\mathrm{K}_{\alpha}$ radiation $(\lambda=1.5404 \AA)$ was used herein. Samples were scanned at a rate of $0.02^{\circ} \cdot$ step $^{-1}$ over the range $5^{\circ} \leq 2 \theta \leq 90^{\circ}\left(\right.$ scan time $=2 \mathrm{~s} \cdot$ step $\left.^{-1}\right)$. The average crystallite size of each sample was calculated from the peak position and full width at half maximum (FWHM) of the peak corresponding to Pd (111) by using the Scherrer equation. 
Table 3. Nominal catalysts metal composition and nomenclature.

\begin{tabular}{|c|c|c|c|c|}
\hline $\begin{array}{c}\text { Catalyst } \\
\text { Nomenclature }\end{array}$ & Pd Content $\left(\%^{*}\right)$ & Sn Content $\left(\%^{*}\right)$ & $\begin{array}{c}\text { Mo Content } \\
(\% *)\end{array}$ & $\operatorname{Re}$ Content $(\% *)$ \\
\hline $20 \% \mathrm{Pd} / \mathrm{C}$ & 100 & - & - & - \\
\hline $20 \% \mathrm{Sn} / \mathrm{C}$ & - & 100 & - & - \\
\hline $20 \% \mathrm{Mo} / \mathrm{C}$ & - & - & 100 & - \\
\hline $20 \% \operatorname{Re} / \mathrm{C}$ & - & - & - & 100 \\
\hline $20 \% \mathrm{Pd}_{70} \mathrm{Sn}_{30} / \mathrm{C}$ & 70 & 30 & - & - \\
\hline $20 \% \mathrm{Pd}_{50} \mathrm{Sn}_{50} / \mathrm{C}$ & 50 & 50 & - & - \\
\hline $\begin{array}{c}20 \% \\
\mathrm{Pd}_{70} \mathrm{Mo}_{30} / \mathrm{C}\end{array}$ & 70 & - & 30 & - \\
\hline $\begin{array}{c}20 \% \\
\mathrm{Pd}_{50} \mathrm{Mo}_{50} / \mathrm{C}\end{array}$ & 50 & - & 50 & - \\
\hline $20 \% \mathrm{Pd}_{70} \operatorname{Re}_{30} / \mathrm{C}$ & 70 & - & - & 30 \\
\hline $20 \% \mathrm{Pd}_{50} \operatorname{Re}_{50} / \mathrm{C}$ & 50 & - & - & 50 \\
\hline
\end{tabular}

\subsection{Electrochemical Characterization in Half-Cell Configuration}

Electrochemical characterization was performed on a half-cell configuration threeelectrode system. In this system, a glass cell contained three electrodes namely, a glassy carbon working electrode, where the catalyst ink was deposited with a geometric area of $0.303 \mathrm{~cm}^{2}$ (Metrohm), an $\mathrm{Ag} / \mathrm{AgCl}$ reference electrode $(\mathrm{KCl}, 3 \mathrm{M}$, Metrohm) and a Pt foil counter electrode (Metrohm). Optical microscopy images of the catalysts supported over the glassy carbon electrode were taken before and after the electrochemical reaction to verify the integrity of the different catalysts studied (Figure S6).

The deposited catalyst ink was prepared by mixing $7 \mathrm{mg}$ of catalyst powder, 20 $\mu \mathrm{L}$ of a $5 \mathrm{wt} \%$ Nafion solution, $0.25 \mathrm{~mL}$ of milli-Q water and $0.75 \mathrm{~mL}$ of isopropanol solvent. The mixture was sonicated for $1 \mathrm{~h}$ until a homogeneous catalyst ink was formed. $10 \mu \mathrm{L}$ of this ink were deposited on the glassy carbon electrode surface and dried at room temperature. Lastly, $2 \mu \mathrm{L}$ of a $5 \mathrm{wt} \%$ Nafion solution was also deposited on the surface in order to immobilize the catalyst ink.

Electrochemical tests were performed on a Voltalab PGZ 301 potentiostat-galvanostat (Radiometer Analytical, Loveland, CO, USA). All the CV measurements were conducted at room temperature. $\mathrm{CV}$ measurements from $-1.0 \mathrm{~V}$ to $0.6 \mathrm{~V}$ at $50 \mathrm{mV} \cdot \mathrm{s}^{-1}$ in $1.0 \mathrm{~mol}$ $1^{-1} \mathrm{KOH}$ solution were carried out in order to measure the electrochemical active surface area of the catalysts. Afterward, for EOR measurement, CV measurements in $1 \mathrm{M} \mathrm{EtOH}$ and $1 \mathrm{~mol} \mathrm{~L}{ }^{-1} \mathrm{KOH}$ solution were carried out from $-1.0 \mathrm{~V}$ to $0.6 \mathrm{~V}$ at $10 \mathrm{mV} \cdot \mathrm{s}^{-1}$. All the solutions were purged with nitrogen before the measurements. In order to ensure that the steady state was reached, more than 40 consecutive cycles were performed for each voltammogram, and results for 30 and 35 cycles are shown in Figure S7.

\subsection{Electrochemical Performance in a Membrane-Less Electrolyzer}

A membrane-less electrochemical electrolyzer with a geometric electrode area of $10.5 \mathrm{~cm}^{2}$ and a liquid solution as electrolyte was used to test the performance of the electrocatalysts. In this system (described in detail elsewhere [6]), the cathode and the anode were arranged in a single chamber reactor configuration where both electrodes were in contact with the same fuel-electrolyte mixture solution. Electrodes (distanced $3.5 \mathrm{~mm}$ from each other) were placed between ethylene propylene diene monomer (EPDM) gaskets and Teflon (PTFE) frames, being contact with the bipolar plates which served as current collectors. Two external Teflon plates covered with metallic end plates finally sealed the uniformly tight cell.

Commercial Pt on carbon black (20\% Pt/C; Alfa Aesar) was used as the cathodic catalyst, and the different synthesized catalysts served as anodes. In each case, a catalyst ink was prepared (by mixing each catalyst powder with isopropanol) and then dispersed on the carbon paper (Fuel Cell Earth) using a preeflow eco-SPRAY controlled by ecocontrol 
SC1200 and ecocontrol EC200 (ViscoTEC). The metal loading was controlled by weight measurements until it reached a value of $1 \mathrm{mg} \cdot \mathrm{cm}^{-2}$ for each electrode.

Electrochemical tests were performed using a Vertex 5 A.DC potentiostat-galvanostat electrochemical analyser (Ivium Technologies, Eindhoven, Netherlands). The anodic and cathodic compartments were fed with $1 \mathrm{M} \mathrm{EtOH}$ and $4 \mathrm{M} \mathrm{KOH}$ aqueous solutions at a constant flow rate of $23 \mathrm{~mL} \cdot \mathrm{min}^{-1}$ using a peristaltic pump (Pumpdrive 5001, Heidolph, Schwabach, Germany). The gas phase of the outlet-stream was separated from the liquid one (by condensation) and measured by a gas volumetric flowmeter. In order to check the purity of the $\mathrm{H}_{2}$ gas-flow rate obtained, the outlet-stream was also analyzed via gas chromatography (Bruker 450-GC, Bruker Daltonik GmbH, Bremen, Germany). Then, the measured $\mathrm{H}_{2}$ gas-flow rate was crosschecked via Faraday's Law calculations, based on the cell current. The liquid feed streams were recirculated to the feeding reservoirs with an overall solution volume of $2 \mathrm{~L}$. Three kinds of electrochemical tests were performed at $85^{\circ} \mathrm{C}$ : linear sweep voltammetry measurements at a scan rate of $10 \mathrm{mV} \cdot \mathrm{s}^{-1}$ in a potential range between 0 and $1.4 \mathrm{~V}$, galvanostatic transients from 0 to $1 \mathrm{~A}$ (to experimentally measure hydrogen production rates) and a chronopotentiometry test at $0.5 \mathrm{~A}$ for $8 \mathrm{~h}$ for stability analysis.

\section{Conclusions}

The effects of the addition of several oxophilic co-metals (i.e., Sn, Re and Mo) on the EOR performance of $\mathrm{Pd}$ were compared herein. XRD revealed slight changes in the size of the Pd nanoparticles upon addition of these co-metals, with no signs of Sn, Re or Mo crystalline phases. The three co-metals tested herein changed the EOR activity of Pd significantly. Sn and Re were found to improve the EOR activity of Pd to a large extent, resulting in normalized peak currents 3-4 times higher than those of the monometallic $\mathrm{Pd} / \mathrm{C}$ catalyst. When added in significant amounts (50:50 ratio), $\mathrm{Sn}$ and Re also increased the electrochemical surface area of $\mathrm{Pd}$ while allowing the oxidation process at lower $\mathrm{E}_{\text {onset }}$ potentials compared to monometallic Pd/C. Overall, Sn was more effective than Re in promoting the EOR activity of $\mathrm{Pd}$, in line with $\mathrm{CV}$ measurements revealing a higher ability of $\mathrm{Sn}$ to adsorb OH species. Unlike $\mathrm{Sn}$ and Re, Mo did not improve the EOR activity of Pd.

The most promising catalysts $\left(\mathrm{Pd}_{50} \mathrm{Re}_{50} / \mathrm{C}\right.$ and $\left.\mathrm{Pd}_{50} \mathrm{Sn}_{50} / \mathrm{C}\right)$ were additionally tested on a membrane-less electrochemical cell. Both catalysts showed higher activities than the monometallic catalysts in the absence of a membrane, although $\mathrm{Pd}_{50} \mathrm{Re}_{50} / \mathrm{C}$ was significantly more stable than $\mathrm{Pd}_{50} \mathrm{Re}_{50} / \mathrm{C}$. Both catalysts generated high-purity hydrogen at high intensity and low voltage conditions, which could lead to significant energy consumption savings compared to commercial water electrolyzers.

Supplementary Materials: The following are available online at https:/ /www.mdpi.com/article/10 $.3390 /$ catal11050541/s1. Figure S1: XRD pattern of carbon Vulcan and different metals studied over carbon: (a) Carbon Vulcan; (b) $20 \% \mathrm{Pd} / \mathrm{C}$; (c) $20 \% \mathrm{Sn} / \mathrm{C}$; (d) $20 \% \mathrm{Mo} / \mathrm{C}$; (e) $20 \% \mathrm{Re} / \mathrm{C}$. Figure S2: Comparison of cyclic voltammograms obtained for the different co-metals ( $20 \% \mathrm{Sn}$, Mo and Re over carbon) and $20 \% \mathrm{Pd} / \mathrm{C}$ catalyst in a solution of $\mathrm{KOH} 1.0 \mathrm{~mol}^{-1}$. $\mathrm{E}(\mathrm{mV}) \mathrm{vs} . \mathrm{Ag} / \mathrm{AgCl}(3 \mathrm{M})$ ). (Scan rate: $50 \mathrm{mV} \mathrm{s}^{-1}$ at room temperature). Figure S3: Comparison of cyclic voltammograms obtained for bimetallic catalysts with different co-metals ( $\mathrm{Sn}, \mathrm{Mo}$ and $\mathrm{Re}$ ) and $\mathrm{Pd} / \mathrm{C}$ catalyst in a solution of $\mathrm{KOH}$ $1.0 \mathrm{~mol} \mathrm{~L}^{-1}$. Figure S4: Performance of the different cometals over carbon in a solution of $\mathrm{KOH} 1.0$ $\mathrm{mol} \mathrm{L}{ }^{-1}+\mathrm{EtOH} 1.0 \mathrm{~mol} \mathrm{~L}^{-1}$. Figure S5: Onset potential for the different catalysts studied.Figure S6: Microscopy images of the sample over the glassy carbon electrode before (left) and after (right) the electrochemical reaction in a solution of $\mathrm{KOH} 1 \mathrm{~mol} \mathrm{~L}^{-1}$ containing EtOH $1 \mathrm{~mol} \mathrm{~L}^{-1}$. Figure S7: Consecutive CVs cycles in a solution of $\mathrm{KOH} 1 \mathrm{~mol}^{-1}$ for: a) Pd/C catalysts; b) Pd-Sn/C catalysts; c) $\mathrm{Pd}-\mathrm{Mo} / \mathrm{C}$ catalysts; d) $\mathrm{Pd}-\mathrm{Re} / \mathrm{C}$ catalysts.

Author Contributions: The conceptualization, methodology, investigation and writing-original draft preparation were performed by E.R.-L. and M.A.D.-P. Equally; writing — review and editing was performed by F.D., A.d.L.-C. and J.C.S.-R. All authors have read and agreed to the published version of the manuscript. 
Funding: J.C.S.-R. would like to thank the Spanish Ministry of Economy, Industry and Competitiveness for financial support through the Ramón y Cajal Program, grant: RYC-2015-19230. J.C.S.-R. would also like to thank Junta de Andalucía for financial support through the projects PY18-RE-0012 and IE18_0047_FUNDACIÓN LOYOLA. In addition, A.d.L.-C. would also like to thank the Spanish Ministry of Economy, Industry and Competitiveness for financial support through the project PID2019-107499RB-I00. J.C.S.-R. would like to thank the Spanish Ministry of Economy, Industry and Competitiveness for financial support through the project PID2019-108453GB-C22.

Data Availability Statement: Data is contained within the article or supplementary material. The data presented in this study are available in www.mdpi.com/xxx/s1.

Acknowledgments: M.A.D.-P. would like to thank the Chemical Engineering Department of the University of Castilla-La Mancha the support and the possibility of a post-doc research internship period in their facilities.

Conflicts of Interest: The authors declare no conflict of interest.

\section{References}

1. Dincer, I.; Acar, C. Review and evaluation of hydrogen production methods for better sustainability. Int. J. Hydrogen Energy 2015, 40, 11094-11111. [CrossRef]

2. Holladay, J.D.; Hu, J.; King, D.L.; Wang, Y. An overview of hydrogen production technologies. Catal. Today 2009, 139, 244-260. [CrossRef]

3. Kumar, S.S.; Himabindu, V. Hydrogen production by PEM water electrolysis-A review. Mater. Sci. Energy Technol. 2019, 2, 442-454. [CrossRef]

4. Rashid, M.; Al Mesfer, M.; Naseem, H.; Danish, M. Hydrogen Production by Water Electrolysis: A Review of Alkaline Water Electrolysis, PEM Water Electrolysis and High Temperature Water Electrolysis. Int. J. Eng. Adv. Technol. 2015, 4, $2249-8958$.

5. Gutiérrez-Guerra, N.; Jiménez-Vázquez, M.; Serrano-Ruiz, J.; Valverde, J.; de Lucas-Consuegra, A. Electrochemical reforming vs. catalytic reforming of ethanol: A process energy analysis for hydrogen production. Chem. Eng. Process. Process. Intensif. 2015, 95, 9-16. [CrossRef]

6. Ruiz-López, E.; Amores, E.; de la Osa, A.R.; Dorado, F.; de Lucas-Consuegra, A. Electrochemical reforming of ethanol in a membrane-less reactor configuration. Chem. Eng. J. 2020, 379, 122289. [CrossRef]

7. Song, S.Q.; Zhou, W.J.; Zhou, Z.H.; Jiang, L.H.; Sun, G.Q.; Xin, Q.; Leontidis, V.; Kontou, S.; Tsiakaras, P. Direct ethanol PEM fuel cells: The case of platinum based anodes. Int. J. Hydrogen Energy 2005, 30, 995-1001. [CrossRef]

8. Almeida, T.D.S.; De Andrade, A.R. New Trends in Direct Ethanol Fuel Cells. New Future Dev. Catal. 2013, 429-452. [CrossRef]

9. Yu, E.H.; Krewer, U.; Scott, K. Principles and Materials Aspects of Direct Alkaline Alcohol Fuel Cells. Energies 2010, 3, 1499-1528. [CrossRef]

10. Xu, C.; Shen, P.K.; Liu, Y. Ethanol electrooxidation on Pt/C and Pd/C catalysts promoted with oxide. J. Power Sources 2007, 164, 527-531. [CrossRef]

11. Liang, Z.; Zhao, T.; Xu, J.; Zhu, L. Mechanism study of the ethanol oxidation reaction on palladium in alkaline media. Electrochim. Acta 2009, 54, 2203-2208. [CrossRef]

12. Takamura, T.; Minamiyama, K. Anodic Oxidation of Methanol at Palladium Electrode in Alkaline Solution. J. Electrochem. Soc. 1965, 112, 333. [CrossRef]

13. Takamura, T.; Sato, Y. Specular reflectivity studies of the adsorption and the oxidation of methanol on palladium in an alkaline solution. Electrochim. Acta 1974, 19, 63-68. [CrossRef]

14. Chen, L.; Lu, L.; Zhu, H.; Chen, Y.; Huang, Y.; Li, Y.; Wang, L. Improved ethanol electrooxidation performance by shortening $\mathrm{Pd}-\mathrm{Ni}$ active site distance in Pd-Ni-P nanocatalysts. Nat. Commun. 2017, 8, 14136. [CrossRef]

15. Monyoncho, E.A.; Ntais, S.; Soares, F.; Woo, T.K.; Baranova, E.A. Synergetic effect of palladium-ruthenium nanostructures for ethanol electrooxidation in alkaline media. J. Power Sources 2015, 287, 139-149. [CrossRef]

16. Yi, Q.; Niu, F.; Song, L.; Liu, X.; Nie, H. Electrochemical Activity of Novel Titanium-Supported Porous Binary Pd-Ru Particles for Ethanol Oxidation in Alkaline Media. Electroanalysis 2011, 23, 2232-2240. [CrossRef]

17. Maumau, T.; Modibedi, R.; Mathe, M. Electro-oxidation of alcohols using carbon supported gold, palladium catalysts in alkaline media. Mater. Today Proc. 2018, 5, 10542-10550. [CrossRef]

18. Adam, A.M.M.; Zhu, A.; Ning, L.; Deng, M.; Zhang, Q.; Liu, Q. Carbon supported PdSn nanocatalysts with enhanced performance for ethanol electrooxidation in alkaline medium. Int. J. Hydrog. Energy 2019, 44, 20368-20378. [CrossRef]

19. Bambagioni, V.; Bianchini, C.; Marchionni, A.; Filippi, J.; Vizza, F.; Teddy, J.; Serp, P.; Zhiani, M. Pd and Pt-Ru anode electrocatalysts supported on multi-walled carbon nanotubes and their use in passive and active direct alcohol fuel cells with an anion-exchange membrane (alcohol=methanol, ethanol, glycerol). J. Power Sources 2009, 190, 241-251. [CrossRef]

20. Na, H.; Zhang, L.; Qiu, H.; Wu, T.; Chen, M.; Yang, N.; Li, L.; Xing, F.; Gao, J. A two step method to synthesize palladium-copper nanoparticles on reduced graphene oxide and their extremely high electrocatalytic activity for the electrooxidation of methanol and ethanol. J. Power Sources 2015, 288, 160-167. [CrossRef] 
21. Douk, A.S.; Saravani, H.; Noroozifar, M. Novel fabrication of PdCu nanostructures decorated on graphene as excellent electrocatalyst toward ethanol oxidation. Int. J. Hydrog. Energy 2017, 42, 15149-15159. [CrossRef]

22. Lv, H.; Sun, L.; Xu, D.; Suib, S.L.; Liu, B. One-pot aqueous synthesis of ultrathin trimetallic PdPtCu nanosheets for the electrooxidation of alcohols. Green Chem. 2019, 21, 2367-2374. [CrossRef]

23. Mattarozzi, L.; Cattarin, S.; Comisso, N.; Gerbasi, R.; Guerriero, P.; Musiani, M.; Vázquez-Gómez, L. Preparation of compact and porous Pd-Ni alloys and study of their performances for ethanol oxidation in alkali. Electrochim. Acta 2019, 307, 503-511. [CrossRef]

24. Wang, Y.; Nguyen, T.S.; Liu, X.; Wang, X. Novel palladium-lead (Pd-Pb/C) bimetallic catalysts for electrooxidation of ethanol in alkaline media. J. Power Sources 2010, 195, 2619-2622. [CrossRef]

25. Lv, H.; Wang, Y.; Lopes, A.; Xu, D.; Liu, B. Ultrathin PdAg single-crystalline nanowires enhance ethanol oxidation electrocatalysis. Appl. Catal. B Environ. 2019, 249, 116-125. [CrossRef]

26. Caglar, A.; Kivrak, H. Highly active carbon nanotube supported PdAu alloy catalysts for ethanol electrooxidation in alkaline environment. Int. J. Hydrog. Energy 2019, 44, 11734-11743. [CrossRef]

27. Geraldes, A.N.; Furtunato da Silva, D.; Martins da Silva, J.C.; Antonio de Sá, O.; Spinacé, E.V.; Neto, A.O.; Coelho dos Santos, M. Palladium and palladium-tin supported on multi wall carbon nanotubes or carbon for alkaline direct ethanol fuel cell. J. Power Sources 2015, 275, 189-199. [CrossRef]

28. da Silva, S.G.; Assumpção, M.H.M.T.; Silva, J.C.M.; de Souza, R.F.; Spinacé, E.V.; Neto, A.O.S.; Buzzo, G.S. PdSn/C Electrocatalysts with Different Atomic Ratios for Ethanol Electro-Oxidation in Alkaline Media. Int. J. Electrochem. Sci. 2014, 9, 5416-5424.

29. Du, W.; MacKenzie, K.E.; Milano, D.F.; Deskins, N.A.; Su, D.; Teng, X. Palladium-Tin Alloyed Catalysts for the Ethanol Oxidation Reaction in an Alkaline Medium. ACS Catal. 2012, 2, 287-297. [CrossRef]

30. Zhang, Z.; Ge, J.; Ma, L.; Liao, J.; Lu, T.; Xing, W. Highly Active Carbon-supported PdSn Catalysts for Formic Acid Electrooxidation. Fuel Cells 2009, 9, 114-120. [CrossRef]

31. Pech-Rodríguez, W.; González-Quijano, D.; Vargas-Gutiérrez, G.; Morais, C.; Napporn, T.; Rodríguez-Varela, F. Electrochemical and in situ FTIR study of the ethanol oxidation reaction on PtMo/C nanomaterials in alkaline media. Appl. Catal. B Environ. 2017, 203, 654-662. [CrossRef]

32. Zhang, X.; Shen, P.K. Glycerol electrooxidation on highly active Pd supported carbide/C aerogel composites catalysts. Int. J. Hydrog. Energy 2013, 38, 2257-2262. [CrossRef]

33. Ambriz-Peláez, O.; Durón, S.; Olivas, A.; Valdez, R.; Arriaga, L.G.; Álvarez-Contreras, L.; Guerra-Balcázar, M.; Arjona, N. Effect of molybdenum content on the morphology and electronic characteristics of $\mathrm{Pd}-\mathrm{MoO}$ nanomaterials and activity evaluation for ethylene glycol electro-oxidation. Appl. Surf. Sci. 2019, 498, 143842. [CrossRef]

34. Lim, E.J.; Kim, H.J.; Kim, W.B. Efficient electrooxidation of methanol and ethanol using MoOx-decorated Pd catalysts in alkaline media. Catal. Commun. 2012, 25, 74-77. [CrossRef]

35. Xiao, J.; Puddephatt, R.J. Pt-Re clusters and bimetallic catalysts. Coord. Chem. Rev. 1995, 143, 457-500. [CrossRef]

36. Tayal, J.; Rawat, B.; Basu, S. Effect of addition of rhenium to Pt-based anode catalysts in electro-oxidation of ethanol in direct ethanol PEM fuel cell. Int. J. Hydrog. Energy 2012, 37, 4597-4605. [CrossRef]

37. Gopi, K.H.; Bhat, S.D.; Sahu, A.K.; Sridhar, P. Quaternized poly(phenylene oxide) anion exchange membrane for alkaline direct methanol fuel cells in KOH-free media. J. Appl. Polym. Sci. 2016, 133, 133. [CrossRef]

38. LaConti, A.B.; Hamdan, M.; McDonald, R.C. Mechanisms of membrane degradation. In Handbook of Fuel Cells; Wiley: Hoboken, NJ, USA, 2010.

39. Collier, A.; Wang, H.; Yuan, X.Z.; Zhang, J.; Wilkinson, D.P. Degradation of polymer electrolyte membranes. Int. J. Hydrog. Energy 2006, 31, 1838-1854. [CrossRef]

40. Zhu, F.; Wang, M.; He, Y.; Ma, G.; Zhang, Z.; Wang, X. A comparative study of elemental additives (Ni, Co and Ag) on electrocatalytic activity improvement of PdSn-based catalysts for ethanol and formic acid electro-oxidation. Electrochim. Acta 2014, 148, 291-301. [CrossRef]

41. Grdeń, M.; Czerwiński, A. EQCM studies on Pd-Ni alloy oxidation in basic solution. J. Solid State Electrochem. 2007, 12, 375-385 [CrossRef]

42. Sankar, S.; Watanabe, N.; Anilkumar, G.M.; Nair, B.N.; Sivakamiammal, S.G.; Tamaki, T.; Yamaguchi, T.; Sasidharan, S.; Sailaja, G. Electro-oxidation competency of palladium nanocatalysts over ceria-carbon composite supports during alkaline ethylene glycol oxidation. Catal. Sci. Technol. 2018, 9, 493-501. [CrossRef]

43. Hamo, E.; Raviv, A.; Rosen, B.A. Influence of Nanocrystalline Palladium Morphology on Alkaline Oxygen Reduction Kinetics. Catalysts 2019, 9, 566. [CrossRef]

44. Kepp, K.P. A Quantitative Scale of Oxophilicity and Thiophilicity. Inorg. Chem. 2016, 55, 9461-9470. [CrossRef] [PubMed]

45. Robinson, A. The Role of Oxophilic Metal Promoters in Bimetallic Hydrodeoxygenation Catalysts. Ph.D. Thesis, University of Colorado at Boulder, Boulder, CO, USA, 2016.

46. Robinson, A.M.; Montemore, M.M.; Tenney, S.A.; Sutter, P.; Medlin, J.W. Interactions of Hydrogen, CO, Oxygen, and Water with Molybdenum-Modified Pt(111). J. Phys. Chem. C 2013, 117, 26716-26724. [CrossRef]

47. Ordóñez, L.; Roquero, P.; Sebastian, P.; Ramírez, J. Carbon-supported platinum-molybdenum electro-catalysts for methanol oxidation. Catal. Today 2005, 107-108, 46-52. [CrossRef] 
48. Bonarowska, M.; Malinowski, A.; Karpiński, Z. Hydrogenolysis of C-C and C-Cl bonds by Pd-Re/Al2O3 catalysts. Appl. Catal. A Gen. 1999, 188, 145-154. [CrossRef]

49. Calcerrada, A.B.; de la Osa, A.R.; Dole, H.A.E.; Dorado, F.; Baranova, E.A.; de Lucas-Consuegra, A. Stability Testing of Pt x Sn1 $\mathrm{x} / \mathrm{C}$ Anodic Catalyst for Renewable Hydrogen Production Via Electrochemical Reforming of Ethanol. Electrocatalysis 2018, 9 , 293-301. [CrossRef]

50. Xu, C.; Shen, P.K. Electrochamical oxidation of ethanol on Pt-CeO2/C catalysts. J. Power Sources 2005, 142, 27-29. [CrossRef]

51. Carmo, M.; Fritz, D.L.; Mergel, J.; Stolten, D. A comprehensive review on PEM water electrolysis. Int. J. Hydrog. Energy 2013, 38, 4901-4934. [CrossRef]

52. Baranova, E.; Bock, C.; Ilin, D.; Wang, D.; MacDougall, B. Infrared spectroscopy on size-controlled synthesized Pt-based nano-catalysts. Surf. Sci. 2006, 600, 3502-3511. [CrossRef] 